\title{
IMPELEMENTASI KEBIJAKAN PENDATAAN PENDUDUK NON PERMANEN DI KABUPATEN BANGKA
}

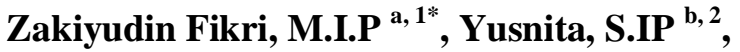 \\ ${ }^{\text {a }}$ STISIPOL Pahlawan 12 Sungailiat, Sungailiat, Bangka 33211 \\ ${ }^{\mathrm{b}}$ STISIPOL Pahlawan 12 Sungailiat, Sungailiat, Bangka 33211 \\ ${ }^{1}$ zakiyudin.fikri@stisipolp12.ac.id *; yusnita96@yahoo.com
}

INFO ARTIKEL

\section{Riwayat Artikel:}

Diterima: 10-04-2020

Disetujui: 27-04-2020

\section{Kata Kunci:}

1. Implementasi Kebijakan

2. Pendataan

3. Penduduk-Non Permanen
Keyword :
1. Policy
Implementation
2. Data collection
3. Non-permanent population

\section{ABSTRAK}

Abstrak: Pertumbuhan penduduk di Kabupaten Bangka setiap tahunnya terus meningkat dan diikuti pula dengan meningkatnya jumlah penduduk pendatang. Pemerintah pusat mengeluarkan Peraturan Menteri Dalam Negeri Nomor 14 Tahun 2015 tentang pedoman pendataan penduduk non permanen. Di Kabupaten Bangka instansi yang melaksanakan kebijakan tersebut adalah Dinas Kependudukan dan Pencatatan Sipil Kabupaten Bangka. Kebijakan tersebut dilaksanakan guna untuk melihat mobilitas penduduk dan untuk mencapai tujuan tertibnya administrasi kependudukan. Penelitian ini membahas mengenai implementasi kebijakan pendataan penduduk nonpermanen dan faktor-faktor yang mempengaruhi implementasi kebijakan pendataan penduduk nonpermanen di Kabupaten Bangka. Penelitian ini adalah penelitian kualitatif dengan metode deskriptif. Tujuan penelitian ini adalah untuk mengetahui implementasi kebijakan pendataan penduduk non permanen dan faktor-faktor yang mempengaruhi implementasi kebijakan pendataan penduduk non permanen di Kabupaten Bangka. Berdasrkan hasil penelitian yang telah peneliti lakukan dilapangan bahwa implementasi kebijakan pendataan penduduk non permanen di Kabupaten Bangka yang dilihat dari dimensi, organisasi, interprestasi dan aplikasi dapat dikatakan sudah cukup baik. Sedangkan faktor-faktor yang mempengaruhi implementasi kebijakan pendataan penduduk non permanen di Kabupaten Bangka yang dilihat dari faktor komunikasi, sumber daya, disposisi, dan struktur birokrasi hasilnya belum baik

\section{Abstract}

Population growth in Bangka Regency continues to increase every year and is followed by an increase in the number of migrants. The central government issued Regulation of the Minister of Home Affairs Number 14 of 2015 concerning guidelines for collecting non-permanent residents. In Bangka Regency, the agency implementing the policy is the Population and Civil Registry Office of Bangka Regency. The policy was implemented 
in order to see population mobility and to achieve the goal of orderly population administration. This study discusses the implementation of the non-permanent population data collection policy and the factors that influence the implementation of the non-permanent population data collection policy in Bangka Regency. This research is a qualitative research with descriptive method. The purpose of this study was to determine the implementation of the non-permanent data collection policy and the factors that influence the implementation of the non-permanent data collection policy in Bangka Regency. Based on the results of research that researchers have done in the field that the implementation of non-permanent population data collection policies in the Regency of Bangka in terms of dimensions, organization, interpretation and application can be said to be quite good. While the factors that influence the implementation of non-permanent population data collection policies in Bangka Regency are seen from the factors of communication, resources, disposition, and bureaucratic structure.

\section{LATAR BELAKANG}

Indonesia merupakan salah satu negara berkembang yang jumlah penduduknya sangat besar. Dengan jumlah penduduk yang besar seperti ini, Indonesia tentunya membutuhkan administrasi kependudukan yang terorganisir dari pusat hingga ke daerah. Administrasi kependudukan menjadi semakin penting karena selalu bersentuhan dengan setiap aktivitas kehidupan sosial di Indonesia. Salah satunya, apabila kita akan berdomisili pada suatu wilayah maka kita harus memiliki tanda domisili yang dibuktikan dengan Kartu Tanda Penduduk (KTP).

Sebagai negara kepulauan Indonesia memiliki persebaran penduduk yang tidak merata, banyak masalah yang merupakan akibat dari persebaran penduduk kerap kali muncul dan mendesak pemerintah untuk segera mengambil sebuah kebijakan.Disamping itu faktor pertumbuhan penduduk yang besar serta persebarannya yang tidak merata dan rendahnya kualitas penduduk juga menjadi suatu permasalahan yang berkaitan dengan kependudukan di Indonesia.

Pertumbuhan penduduk mungkin sudah tidak asing lagi didengar oleh semua orang, tapi ini merupakan suatu masalah yang sangat sulit untuk diatasi dan jika itu terus terjadi maka semakin banyak masalah yang akan terjadi seperti pengangguran, pencurian yang akan menimbulkan masalah-masalah baru. Berdasarkan data yang ada di BPS Kabupaten Bangka pertumbuhan penduduk di Kabupaten Bangka setiap tahunnya terus meningkat. Jumlah penduduk di Kabupaten Bangka pada tahun 2015 berjumlah 311.085 jiwa, di tahun 2016 yaitu 317.735 jiwa dan pada tahun 2017 sebesar 324.305 jiwa.

Seiring dengan lajunya pertumbuhan penduduk di Kabupaten Bangka, pertumbuhan jumlah penduduk pendatang pun semakin terus meningkat dengan tumbuhnya pembangunan yang ada sehingga memberikan peluang yang sangat besar untuk penduduk diluar Kabupaten Bangka berdatangan mencari sumber penghasilan.Kabupaten Bangka termasuk daerah yang dipilih para pendatang untuk mencari rezeki di Bumi Sepintu Sedulang ini. Sektor pertambangan menjadi magnet yang menarik para pendatang hijrah ke Kabupaten Bangka. Sebagian pendatang bukan hanya mencari pekerjaan disektor pertambangan, tetapi juga disektor lain seperti di sektor perkebunan.

Fenomena ini akan semakin tidak terkendali jika pemerintah daerah tidak bijak dalam 
menyikapinya. Akan banyak permasalahan kependudukan yang muncul dari efek euphoria ini disebabkan banyaknya pendatang yang datang dapat dikategorikan sebagai penduduk musiman, artinya penduduk ini tidak selamanya menetap atau menjadi penduduk tetap di Kabupaten Bangka. Ketika penduduk pendatang tidak lagi mendapatkan pekerjaan seperti di sektor pertambangan yang semakin habis maka akibat yang akan timbul dari banyaknya pendatang yang tidak memiliki pekerjaan yakni kejahatan atau permasalah sosial serta tindakan kriminal seperti kasus pencurian.

Pemerintah terkait dengan hal ini telah membuat suatu kebijakan tentang bagaimana menetralisir keberadaan penduduk pendatang dengan mengeluarkan kebijakan yang dituangkan dalam Peraturan Menteri Dalam Negeri Nomor 14 Tahun 2015 tentang Pedoman Pendataan Penduduk Non Permanen. Dalam Pasal 1 Peraturan Menteri Dalam Negeri Nomor 14 Tahun 2015 yang dimaksud dengan penduduk non permanen adalah penduduk warga negara Indonesia yang bertempat tinggal diluar wilayah kabupaten atau kota tempat tinggal tetapnya yang berbeda dengan alamat pada KTP elektronik yang dimilikinya dan tidak berniat untuk pindah menetap.

Kabupaten Bangka melalui Dinas
Kependudukan dan Pencatatan Sipil telah melaksanakan pendataan penduduk non permanen. Pelaksanaan pendataan penduduk non permanen ini penting untuk dilaksanakan guna untuk mewujudkan tertib administrasi kependudukan. Dengan tertib administrasi seperti dokumen kependudukan diharapkan penduduk yang mempunyai dokumen kependudukan yang resmi dengan temat tinggalnya, akan mempermudah mendapatkan fasilitas yang diberikan pemerintah, seperti di Kabupaten Bangka banyak terdapat program-program yang diberikan pemerintah seperti, santunan kematian, fasilitas kesehatan yang gratis, akta kelahiran dan kematian gratis dan lain sebagainya.

Melalui penelitian ini penulis ingin menganalisa proses dan faktor-faktor yang mempengaruhi pelaksanaan kebijakan pendataan penduduk non permanen, karena semakin meningkatnya penduduk pendatang menjadi sebuah dilema tersendiri bagi pemerintah.

\section{TINJAUAN PUSTAKA}

\section{IMPLEMENTASI}

Implementasi berasal dari bahasa inggris yaitu to implement yang berarti mengimplementasikan. Implementasi merupakan penyediaan sarana untuk melaksanakan sesuatu yang menimbulkan dampak atau akibat terhadap sesuatu. Sesuatu tersebut dilakukan untuk menimbulkan dampak atau akibat itu dapat berupa undang-undang, peraturan pemerintah, keputusan peradilan dan kebijakan yang dibuat oleh lembaga-lembaga pemerintah dalam kehidupan kenegaraan.

Secara etimologis pengertian implementasi menurut Kamus Webster yang dikutip oleh Solichin (dalam Wahab 2005:64) adalah: "Konsep implementasi berasal dari bahasa inggris yaitu to implement. Dalam kamus besar webster, to implement (mengimplementasikan) berati to provide the means for carrying out (menyediakan sarana untuk melaksanakan sesuatu); dan to give practical effect to (untuk menimbulkan dampak/akibat terhadap sesuatu)."

Mazmanian dan Sebastiar dalam Wahab ( 2005:68) juga mendefinisikan implementasi sebagai berikut: Implementasi adalah pelaksanaan keputusan kebijakan dasar, biasanya dalam bentuk undang-undang, namun dapat pula berbentuk perintah-perintah atau keputusan-keputusan eksekutif yang penting atau keputusan badan peradilan.

Implementasi menurut Mazmanian dan Sebastier merupakan pelaksanaan kebijakan dasar berbentuk undang-undang juga berbentuk perintah atau keputusan-keputusan yang penting atau seperti keputusan badan peradilan. Proses implementasi ini berlangsung setelah melalui sejumlah tahapan tertentu seperti tahapan pengesahan undang-undang, kemudian output kebijakan dalam bentuk pelaksanaan keputusan dan seterusnya sampai perbaikan kebijakan yang bersangkutan.

Dari beberapa pendapat para ahli diatas, maka dapat diambil suatu kesimpulan pengertian bahwa implementasi adalah suatu proses yang melibatkan 
sejumlah sumber yang termasuk manusia, dana dan kemampuan organisasional yang dilakukan oleh pemerintah maupun swasta (individu atau kelompok). Proses tersebut dilakukan untuk mencapai tujuan yang telah ditetapkan sebelumnya oleh pembuat kebijakan.

\section{KEBIJAKAN}

Dewasa ini istilah kebijakan lebih sering dan secara luas digunakan dalam kaitannya dengan tindakan atau kegiatan pemerintah seperti perilaku negara pada umumnya. Untuk melihat keberhasilan suatu kebijakan dan tindakan dalam pengambilan keputusan, maka sangat bergantung pada implementasi kebijakan itu sendiri. Secara etimologis, istilah kebijakan atau policy berasal dari bahasa yunani "polis" berarti negara, kota yang kemudian masuk ke dalam bahasa latin menjadi "politia" yang berarti negara. Akhirnya masuk ke dalam bahasa inggris "policie" yang artinya berkenaan dengan pengendalian masalah-masalah publik atau administrasi pemerintahan. Istilah "kebijakan" atau "policy" dipergunakan untuk menunjuk perilaku seorang aktor (misalnya seorang pejabat,suatu kelompok maupun suatu badan pemerintah) atau sejumlah aktor dalam suatu bidang kegiatan tertentu.

Budi Winarno (2008:16) menyebutkan secara umum istilah "kebijakan" atau "policy" digunakan untuk menunjuk perilaku seorang aktor (misalnya seorang pejabat, suatu kelompok maupun suatu lembaga pemerintahan atau sejumlah aktor dalam suatu bidang kegiatan tertentu, pengertian kebijakan seperti ini dapat kita gunakan dan relatif memadai untuk pembicaraan-pembicaraan biasa, namun menjadi kurang memadai untuk pembicaraanpembicaraan yang lebih bersifat ilmiah dan sistematis menyangkut analisis kebijakan publik oleh karena itu diperlukan batasan atau konsep kebijakan publik yang lebih tepat.

Setiap proses dalam suatu kebijakan tentunya sangat penting karena hal tersebut sangat berkaitan dengan tercapainya suatu tujuan dari kebijakan itu sendiri. Di dalam prosesnya, setelah kebijakan publik terbentuk maka tahap selanjutnya yaitu pengimplementasian agar dapat dilihat apa saja hal- hal yang muncul bagi positif maupun negatif agar tujuan tersebut dapat tercapai, sehingga tujuan yang dicita-citakan dalam kebijakan tersebut dapat tercapai. Tujuan kebijakan sendiri tidak akan tercapai jika kebijakan tidak diimplementasikan atau dimplementasikan dengan tidak baik. Hal ini jelas menunjukkan bahwa implementasi sebagai bagian terpenting dari sebuah kebijakan karena menyumbang 60 persen keberhasilan dari kebijakan itu sendiri.

Menurut Charles O.Jones dalam Budi Winarno (2008:16) istilah kebijakan (policy term) digunakan dalam praktek sehari-hari namun digunakan untuk menggantikan kegiatan atau keputusan yang sangat berbeda. Istilah ini sering dipertukarkan dengan tujuan (goals), program, keputusan (decisions), standard, proposal, dan grand design. Namun demikian, meskipun kebijakan publik mungkin kelihatannya sedikit abstrak atau mungkin dapat dipandang sebagai sesuatu yang terjadi terhadap seseorang.

Frederickson dan Hart dalam Tangkilisan (2003:19) mengemukakan kebijakan adalah suatu tindakan yang mengarah pada tujuan yang diusulkan oleh seseorang, kelompok atau pemerintah dalam lingkungan tertentu sehubungan adanya hambatan-hambatan tertentu sambil mencari peluang-peluang untuk mencapai tujuan atau mewujudkan sasaran yang diinginkan. Sedangkan menurut Carl Friedrich dalam Wahab (2005:3) kebijakan adalah suatu tindakan yang mengarah pada tujuan yang diusulkan oleh seseorang, kelompok, atau pemerintah dalam lingkungan tertentu sehubungan dengan adanya hambatan tertentu seraya mencari peluang-peluang untuk mencapai tujuan atau mewujudkan sasaran yang diinginkan. Selanjutnya Riant Nugroho.D (2008:158) mengemukakan bahwa kebijakan publik yang bisa langsung dioperasionalkan antara lain keputusan presiden, instruksi presiden, keputusan menteri, keputusan kepala daerah serta keputusan kepala dinas.

Dilihat penjelasan kebijakan menurut pendapat para ahli diatas dapat disimpulkan bahwa kebijakan merupakan upaya atau tindakan untuk mempengaruhi sistem pencapaian tujuan yang 
diinginkan, kegiatan yang dibuat oleh suatu individu atau kelompok yang nantinya diimplementasikan ke suatu lingkungan dan kegiatan tersebut memiliki suatu tujuan yang hendak dicapai. Kebijakan juga dapat disimpulkan sebagai aturan tertulis yang merupakan keputusan formal organisasi yang bersifat mengikat anggota yang terkait dengan organisasi tersebut yang dapat mengatur perilaku dengan tujuan menciptakan tata nilai baru dalam masyarakat.

\section{IMPLEMENTASI KEBIJAKAN}

Implementasi kebijakan pada prinsipnya merupakan cara agar sebuah kebijakan dapat mencapai tujuannya. Implementasi kebijakan menurut Riant Nugroho (2008:158) terdapat dua pilihan untuk mengimplementasikannya, yaitu langsung mengimplementasikannya dalam bentuk program-program dan melalui formulasi kebijakan derivat atau turunan dari kebijakan tersebut. Oleh karena itu, implementasi kebijakan yang telah dijelaskan oleh Nugroho merupakan dua pilihan, dimana yang pertama langsung mengimplementasi dalam bentuk program dan pilihan kedua melalui formulasi kebijakan.

Implementasi kebijakan dalam pemerintah yang luas, merupakan alat administrasi hukum dimana berbagai aktor, organisasi, prosedur, dan teknik bekerja bersama-sama untuk menjalankan kebijakan guna merahi dampak atau tujuan yang diinginkan. Implementasi dari sisilain merupakan fenomena yang kompleks, munkin dapat dipahami sebagai proses, keluaran (output) maupun sebagai hasil.

Menurut Van Meter dan Van Horn dalam Winarno (2007:65), proses implementasi sebagai: "Those actions by public or private individuals (or groups) that are directed at the achievement of objectives set forthe in prior decisions (tindakantindakan yang dilakukan baik oleh individu individu/pejabatpejabat/kelompok-kelompok

pemerintah atau swasta yang diarahkan pada tercapainya tujuan-tujuan yang telah digariskan dalam keputusan kebijaksanaan)."

Budi Winarno dalam bukunya yang berjudul Teori dan Proses Kebijakan Publik (2005:101) menjelaskan pengertian implementasi kebijakan, sebagai berikut: Implementasi kebijakan merupakan alat administrasi hukum dimana berbagai aktor, organisasi, prosedur, dan teknik yang bekerja bersamasama untuk menjalankan kebijakan guna meraih dampak atau tujuan yang diinginkan.

Berdasarkan pendapat Winarno tersebut, implementasi kebijakan dipandang dalam pengertian yang luas merupakan fenomena yang kompleks yang mungkin dapat dipahami sebagai proses keluaran (output) maupun hasil, yang melibatkan aktor, organisasi prosedur dan teknik untuk mencapai tujuan yang diinginkan.

Charles O. Jones dalam Joko Widodo (2007:89) mengemukakan teori implementasi kebijakan yang terdiri dari tiga aktivitas utama yang sangat penting dalam implementasi kebijakan, yaitu organization, interpretation, and application. Selengkapnya Jones mengemukakan bahwa aktivitas implementasi kebijakan terdapat tiga macam, antara lain sebagai berikutLester dan Stewart yang dikutip oleh Winarno (2005:101) menjelaskan bahwa implementasi kebijakan adalah: Implementasi kebijakan dipandang dalam pengertian luas merupakan alat administrasi hukum dimana berbagai aktor, organisasi, prosedur dan teknik yang bekerja bersama-sama untuk menjalankan kebijakan guna meraih dampak atau tujuan yang diinginkan.

[1]Organization: the establishment or rearrangement of resources, unit and methods for putting a policy into effect

[2]Interpretation: the translation of program language (often contaned in a statute) into acceptable and feasible plans and directives

[3]Application: the routine provision of service, paymens, or other agree upon objectives of instruments

Aktivitas pengorganisasian (organization) merupakan suatu upaya untuk menetapkan dan menata kembali sumber daya (resources), unit-unit (units), dan metode-metode (methods) yang mengarah pada upaya mewujudkan merelisasikan kebijakan menjadi hasil (outcome) sesuai dengan apa yang menjadi tujuan dan sasaran kebijakan. Aktivitas interpretasi (interpretation) merupakan aktivitas interprestasi (penjelasan) substansi dari suatu kebijakan dalam bahasa yang lebih operasional dan mudah dipahami sehingga dapat dilaksanakan dan diterima oleh para pelaku dan 
sasaran kebijakan. Aktivitas aplikasi (application) merupakan aktivitas penyediaan pelayanan secara rutin, pembayaran atau lainnya sesuai dengan tujuan dan sarana kebijakan yang ada.

\section{Faktor-Faktor Yang Mempengaruhi Impelemntasi Kebijakan}

Implementasi kebijakan sesungguhnya bukan sekedar berhubungan dengan penerjemahan pernyataan kebijakan (policy statement) kedalam aksi kebijakan (policy action). Dalam aktifitas implementasi terdapat berbagai faktor-faktor yang akan mempengaruhi terlaksananya kegiatan atau kebijakan tersebut. Secara umum faktor-faktor yang mempengaruhi implementasi telah banyak dikemukakan oleh para ahli kebijakan diantaranya sebagaimana dikemukakan oleh Edward III, Donald. S. Van. Meter dan Carl E. Van Horn, serta Merilee S. Grindle yang akan penulis uraikan dibawah ini:

Keberhasilan suatu implementasi kebijakan menurut Edward III dalam Riant Nugroho (2017:747) menyarankan untuk memperhatikan empat isu pokok agar implementasi kebijakan menjadi efektif, yaitu communication, resource, disposition or attitudes, and bureaucratic structure.

1. Komunikasi berkenaan dengan bagaimana kebijakan dikomunikasikan kepada organisasi dan/ atau publik dan sikap serta tanggapan dari para pihak yang terlibat.

2. Sumber daya berkenaan dengan ketersediaan sumberdaya pendukung, khususnya sumber daya manusia, di mana hal ini berkenaan dengan kecakapan dari pelaksana kebijakan publik untuk carry out kebijakan secara efektif.

3. Disposisi berkenaan dengan kesediaan dan komitmen untuk melaksankan kebijakan.

4. Struktur birokrasi berkenaan dengan kesesuaian organisasi birokrasi yang menjadi penyelenggara implementasi kebijakan publik. Tantangannya adalah bagaimana agar tidak terjadi bureaucratic fragmentation, karena ini menjadikan proses implementasi menjadi jauh dari efektif.

Menurut Donald Van Meter dan Carl Van Horn dalam Riant Nugroho (2017:738-739) menawarkan suatu model dasar dalam implementasi kebijakan. Model ini mengandaikan bahwa implementasi kebijakan berjalan secara linear dari kebijakan publik, implementor, dan kinerja kebijakan publik. Model yang mereka tawarkan mempunyai enam (6) variabel, variabel-variabel tersebut adalah:

1. Standar dan sasaran kebijakan: para pelaksana memahami standar dan tujuan kebijakan, karena standar dan tujuan kebijakan berhubungan dengan sikap para pelaksana.

2. Sumber daya: kemampuan memanfaatkan sumber daya yang tersedia misalnya sumber daya manusia, uang dan waktu.

3. Karakteristik organisasi pelaksana: prosedurprosedur kerja standar $(\mathrm{SOP}=$ Standard Operating Procedures).

4. Komunikasi antar organisasi terkait dan kegiatan-kegiatan pelaksanaan: ada kejelasan dan konsistensi serta keseragaman terhadap suatu standar dan tujuan kebijakan.

5. Sikap para pelaksana: kebijakan publik biasanya bersifat top down yang sangat mungkin para pengambil keputusan tidak mengetahui bahkan tak mampu menyentuh kebutuhan, keinginan atau permasalahan yang harus diselesaikan.

6. Lingkungan sosial, ekonomi dan politik: lingkungan eksternal kebijakan publik.

Selanjutnya, keberhasilan implementasi menurut Merilee S. Grindle dalam Riant Nugroho (2017:745) dipengaruhi oleh dua (2) variabel besar yakni isi kebijakan dan konteks implementasinya. Isi kebijakan mencakup:

1. Kepentingan yang terpengaruhi oleh kebijakan

2. Jenis manfaat yang akan dihasilkan

3. Derajat perubahan yang diinginkan

4. Kedudukan pembuat kebijakan

5. (Siapa) pelaksana

6. Sumberdaya yang dikerahkan 
Sementara itu konteks implementasinya adalah:

1. Kekuasaan, kepentingan dan strategi aktor yang terlibat

2. Karaktersitik lembaga dan penguasa

3. Kepatuhan dan daya tanggap.

Untuk dapat mengkaji dengan baik suatu implementasi kebijakan perlu diketahui variabel atau faktor-faktor penentunya. Untuk menggambarkan secara jelas variabel atau faktorfaktor yang berpengaruh penting terhadap implementasi kebijakan publik serta guna penyederhanaan pemahaman, maka peneliti akan menggunakan model-model implementasi kebijakan yaitu model yang dikemukakan oleh Edward III dalam Riant Nugroho (2017:747) faktor-faktornya yakni komunikasi, sumberdaya, disposisi dan struktur birokrasi.

Implementasi kebijakan publik merupakan salah satu tahapan dari proses kebijakan publik (public policy process sekaligus studi yang crucial). Bersifat crucial karena bagaimanapun baiknya suatu kebijakan publik, kalau tidak dipersiapkan dan direncanakan secara baik dalam implementasinya, maka tujuan kebijakan tidak akan bisa diwujudkan. Demikian pula sebaliknya, bagaimanapun baiknya persiapan dan perencanaan implementasi kebijakan, kalau tidak dirumuskan dengan baik maka tujuan kebijakan juga tidak akan bisa diwujudkan. Dengan demikian, kalau menghendaki tujuan kebijakan dapat dicapai dengan baik, maka bukan saja pada tahap implementasi yang harus dipersiapkan dan direncanakan dengan baik, tetapi juga pada tahap perumusan atau pembuatan kebijakan juga telah diantisipasi untuk dapat diimplementasikan.

Jika suatu kebijakan tidak tepat atau tidak dapat mengurangi masalah yang merupakan sasaran kebijakan, maka kebijakan itu dapat mengalami kegagalan sekalipun kebijakan tersebut diimplementasikan dengan sangat baik. Sementara itu, suatu kebijakan yang telah direncanakan dengan sangat baik, dapat mengalami kegagalan jika kebijakan tersebut kurang diimplementasikan dengan baik oleh para pelaksana kebijakan.

Implementasi kebijakan sesungguhnya bukan sekedar berhubungan dengan penerjemahan pernyataan kebijakan (policy statement) kedalam aksi.

kebijakan (policy action). Dalam aktifitas implementasi terdapat berbagai factor-faktor yang akan mempengaruhi terlaksananya kegiatan atau kebijakan tersebut.

Keberhasilan suatu implementasi kebijakan menurut Edward III dalam Riant Nugroho (2017:747) menyarankan untuk memperhatikan empat isu pokok agar implementasi kebijakan menjadi efektif, yaitu communication, resource, disposition or attitudes, and bureaucratic structure.

[1] Komunikasi berkenaan dengan bagaimana kebijakan dikomunikasikan kepada organisasi dan/ atau publik dan sikap serta tanggapan dari para pihak yang terlibat.

[2] Sumber daya berkenaan dengan ketersediaan sumberdaya pendukung, khususnya sumber daya manusia, di mana hal ini berkenaan dengan kecakapan dari pelaksana kebijakan publik untuk carry out kebijakan secara efektif.

[3] Disposisi berkenaan dengan kesediaan dan komitmen untuk melaksankan kebijakan.

[4] Struktur birokrasi berkenaan dengan kesesuaian organisasi birokrasi yang menjadi penyelenggara implementasi kebijakan publik. Tantangannya adalah bagaimana agar tidak terjadi bureaucratic fragmentation, karena ini menjadikan proses implementasi menjadi jauh dari efektif.

Berdasarkan teori-teori para ahli diatas, untuk dapat mengkaji dan meneliti dengan baik suatu implementasi kebijakan maka peneliti akan menggunakan teori Charles O. Jones dalam Joko Widodo (2007:89) diantaranya organisasi, interpretasi dan aplikasi. 


\section{METODE PENELITIAN}

\section{a. Jenis Penelitian}

Jenis penelitian ini bersifat deskriptif dengan pendekatan kualitatif. Menurut Atherton \& Klemmack dalam Irawan Soehartono (2002:35) penelitian deskriptif merupakan penelitian yang bertujuan untuk memberikan gambaran tentang suatu masyarakat atau suatu kelompok orang tertentu atau gambaran tentang suatu gejala atau hubungan antara dua gejala atau lebih.

\section{b. Jenis Data}

Dalam Kamus Besar Bahasa Indonesia, data diartikan sebagai kenyataan yang ada yang berfungsi sebagai bahan untuk menyatakan suatu pendapat, keterangan yang benar, dan bahan yang dapat dipergunakan untuk penalaran yang benar, dan bahan yang dapat dipergunakan untuk penalaran dan penyelidikan. Suharsimi dalam M. Djamal (2015:63) mengatakan bahwa data adalah hasil pencatatan seorang peneliti baik yang berupa fakta atau angka. Pendapat lain oleh Emzir dalam M. Djamal (2015:63) mengatakan bahwa data meliputi semua hal yang dicatat dan ditemukan peneliti secara aktif selama studi, seperti transkip wawancara, catatan hasil pengamatan, catatan harian, foto dan dokumen.

Arikunto (2006:224) menyatakan bahwa sumber data adalah subjek darimana data dapat diperoleh dan untuk memudahkan peneliti dalam mengidentifikasi sumber data, peneliti telah menggunakan rumus 3P, yaitu :

a) Person (orang) merupakan tempat dimana peneliti bertanya mengenai variabel yang diteliti.

b) Paper (kertas) adalah tempat peneliti membaca dan mempelajari segala sesuatu yang berhubungan dengan penelitian, seperti arsip, angka, gambar, dokumen-dokumen, simbol-simbol dan lain sebagainya.

c) Place (tempat) yaitu tempat berlangsungnya kegiatan yang berhubungan dengan penelitian.

Sedangkan menurut Lofland dan Lofland dalam Moleong (2007:157) sumber data utama dalam penelitian kualitatif adalah kata-kata dan tindakan orang-orang yang diamati atau diwawancarai, selebihnya adalah data tambahan seperti dokumen dan lain-lain. Lebih lanjut menurut Moleong (2007:6) data yang dikumpulkan sendiri dapat berupa kata-kata atau gambar dan bukan dalam bentuk angka. Sehingga laporan penilitian akan berisi kutipan-kutipan data untuk memberi gambaran penyajian laporan tersebut. Data tersebut mungkin berasal dari naskah wawancara, catatan laporan, foto video tape, dokumen pribadi dan memo.

Adapun sumber data yang dipakai dalam penelitian ini yaitu menggunakan 2 (dua) sumber data antara lain: (1) data primer bersumber dari hasil wawancara dengan informan (2) data sekunder yang digunakan adalah peraturan perundangundangan, literatur-literatur, dokumen-dokumen yang dikeluarkan oleh pemerintah yang berkaitan dengan permasalahan yang diteliti.

\section{c. Teknik Pengumpulan Data}

Sugiyono (2007:62) menjelaskan bahwa teknik pengumpulan data merupakan langkah yang paling strategis dalam penelitian, karena tujuan utama dari penelitian adalah mendapatkan data.

[1] Observasi yaitu dengan melakukan pengamatan langsung terhadap kegiatan pelaksanaan pendataan penduduk nonpermanen yang dilaksanakan oleh Dinas Kependudukan dan Pencatatan Sipil Kabupaten Bangka.

[2] Wawancara dilakukan dengan menanyakan kepada informan mengenai hal-hal yang berhubungan dengan tema penelitian.

[3] Dokumentasi yaitu dengan melakukan pengumpulan data berupa dokumendokumen yang relevan untuk diteliti seperti dokumen peraturan perundangundangan, artikel, pemberitaan di media massa dan dokumen lainnya yang terkait dengan konteks penelitian dan dibutuhkan sebagai bahan dasar dan orientasi teori dalam melakukan analisis data.

\section{d. Metode Analisis Data}


Miles dan Huberman seperti dikutip Sugiyono dalam M. Djamal (2015: 145) mengemukakan bahwa kegiatan analisis data kualitatif dilakukan secara interaktif dan berlangsung secara terus menerus hingga datanya mencapai titik jenuh. Proses analisis data yaitu reduksi data, penyajian data dan pengambilan kesimpulan merupakan proses yang saling berinteraksi satu sama lain sehingga dapat disebut sebagai interactive model. Dalam penelitian ini, peneliti menggunakan teknik analisis dengan model analisis interaktif, yaitu analisis yang bergerak dalam tiga komponen, yaitu (1) Reduksi Data (reduction), (2) Penyajian Data (display data) dan (3) Kesimpulan (conclusion).

\section{Pembahasan}

Pelaksanaan pendataan penduduk non permanen dilakukanberdasarkan Undang-Undang Nomor 24 Tahun 2013 tentang Administarsi Kependudukan, serta Peraturan Menteri Dalam Negeri Nomor 14 Tahun 2015 tentang Pedoman Pendataan Penduduk Non Permanen. Secara sosiologis, penduduk dinamakan sebagai masyarakat yaitu sekumpulan manusia yang dipersatukan oleh suatu rasa persamaan dan yang bersama-sama mendiami suatu wilayah tertentu. Menurut Soepomo (2007: 177), penduduk ialah orang yang dengan sah bertempat tinggal tetap dalam suatu negara.

Peraturan Menteri Dalam Negeri Nomor 14 Tahun 2015 tentang Pedoman Pendataan Penduduk Non Permanen Pasal 1 angka 3 menjelaskan penduduk non permanen adalah penduduk WNI yang bertempat tinggal di luar wilayah kabupaten/kota tempat tinggal tetapnya yang berbeda dengan alamat pada KTP-el dimilikinya dan tidak berniat untuk pindah menetap. Menurut P.N.H Simanjuntak (2014: 177), penduduk non permanen adalah penduduk dari suatu wilayah ke wilayah lain dengan tidak ada niat untuk menetap di daerah tujuan.

Penduduk suatu daerah menjadi sangat krusial fungsinya bagi pemerintah daerah. Mengingat sifatnya yang sangat penting, kondisi penduduk menjadi salah satu tolak ukur pemerintah daerah dalam mengambil berbagai kebijakan strategis dalam pembangunan. Dengan data kependudukan yang benar, akurat dan dapat dipertanggungjawabkan, akan memperbesar tingkat keberhasilan suatu kebijakan.

Jika suatu kebijakan tidak tepat atau tidak dapat mengurangi masalah yang merupakan sasaran kebijakan, maka kebijakan itu dapat mengalami kegagalan sekalipun kebijakan tersebut diimplementasikan dengan sangat baik. Sementara itu, suatu kebijakan yang telah direncanakan dengan sangat baik, dapat mengalami kegagalan jika kebijakan tersebut kurang diimplementasikan dengan baik oleh para pelaksana kebijakan. Implementasi kebijakan pendataan penduduk nonpermanen di Kabupaten Bangka haruslah dilakukan sesuai dengan tujuan dan sasaran yang ingin dicapai.

Implementasi kebijakan dapat dilihat dari beberapa dimensi, seperti yang dikemukakan oleh Charles O. Jones dalam Joko Widodo (2007: 89) dengan melalui tiga dimensi yaitu organisasi, interprestasi dan aplikasi:

1. Organization: the establishment or rearrangement of resources, unit and methods for putting a policy into effect. (Organiasi: suatu upaya untuk menetapkan dan menata kembali sumber daya (resources), unit-unit (units), dan metode-metode (methods) yang mengarah pada upaya mewujudkan merelisasikan kebijakan menjadi hasil (outcome) sesuai dengan apa yang menjadi tujuan dan sasaran kebijakan.

2. Interpretation: the translation of program language (often in a statute) into acceptable and feasible plans and directives. (Interprestasi: aktivitas interprestasi (penjelasan) substansi dari suatu kebijakan dalam bahasa yang lebih operasional dan mudah dipahami sehingga dapat dilaksanakan dan diterima oleh para pelaku dan sasaran kebijakan).

3. Application: the routine provision of service, paymens, or other agree upon objectives of instruments. (Aplikasi: aktivitas penyediaan pelayanan secara rutin, pembayaran atau lainnya sesuai dengan tujuan dan sarana kebijakan yang ada).

Hasil penelitian ini merupakan rangkuman dari observasi dan wawancara dengan berbagai pihak 
tentang pelaksanaan pendataan penduduk non permanen di Kabupaten Bangka.

\section{(a) Organisasi}

Dimensi organisasi digunakan untuk melihat sejauh mana tujuan kebijakan dapat dicapai, pemerintah haruslah melakukan tindakan berupa sumber daya dan pengelolaan sumber daya. Setiap organisasi harus memiliki struktur organisasi, adanya sumber daya manusia yang berkualitas sebagai pelaksana dan perlengkapan atau alat-alat kerja. Deskripsi dimensi organisasi adalah suatu organisasi yang ditunjuk dan dapat melaksanakan semua perintah berdasarkan peraturan perundangundangan yang berlaku, agar arah tujuan dari kebijakan tersebut dapat tercapai sesuai target yang telah ditentukan. Deskripsi dimensi organisasi di sini terdari dari beberapa indikator diantaranya, penataan kembali sumber daya, unit-unit serta metode-metode untuk menjalankan kebijakan. Deskripsi dimensi organisasi mengenai masalah implementasi kebijakan pendataan penduduk non permanen di Kabupaten Bangka dapat dilihat dari hasil wawancara yang dilakukan peneliti kepada berbagai implementor.

Penataan kembali sumber daya merupakan salah satu bentuk untuk mengatur kembali dan menggunakan sumber daya yang dimiliki secara maksimal agar tujuan dari organisasi tersebut dapat tercapai. Penataan kembali sumber daya ini adalah sumber daya manusia (pegawai/aparatur) yang berkualitas sebagai pelaksana. Indikator ini digunakan peneliti untuk melihat implementasi kebijakan pendataan penduduk non permanen di Kabupaten Bangka.

Selanjutnya untuk ketersediaan sumber daya. Sumber daya merupakan aspek penting dalam pelaksanaan suatu kebijakan, hal ini karena keberadaan sumber daya dapat mempengaruhi keberhasilan suatu kebijakan. Agar dapat dilaksanakan dengan baik, kesiapan sumberdaya pelaksana kebijakan adalah hal penting untuk diperhatikan. Sumber daya yang diperlukan dalam menjalankan suatu program terdiri dari beberapa macam yaitu: sumber daya manusia, sumber daya finansial, dan sumber daya sarana dan prasarana.
Dalam dimensi organisasi, hubungan kerja antar pelaksana kebijakan pendataan penduduk nonpermanen di Kabupaten Bangka sudah cukup baik. Bentuk kerjasama antar instansi maupun lembaga antara Dinas Kependudukan dan Pencatatan Sipil, Kecamatan, Kelurahan serta di tingkat bawah yaitu Kepala Lingkungan/RT sebagai penyampai informasi kepada penduduk pendatang yang berperan sebagai sasaran kebijakan dilakukan dengan cara sosialisasi dan koordinasi mengenai pelaksanaan kebijakan pendataan penduduk non permanen.

Terkait dimensi organisasi dalam hal kuantitas sumber daya manusia untuk pelaksanaan kebijakan pendataan penduduk nonpermanen di Kabupaten Bangka masih kurang untuk beberapa kegiatan khususnya untuk perekapan data dan juga proses pengawasan yang meliputi kegiatan monitoring, evaluasi dan pembuatan laporan surat keterangan. Karena seperti yang peneliti temukan di lapangan, belum ada data penduduk non permanen yang direkapitulasi di Dinas Kependudukan dan Pencatatan Sipil Kabupaten Bangka, sedangkan kualitas sumber daya manusia untuk kompetensi dalam melaksanakan kebijakan dari pemberian wewenang dan tanggungjawab sudah cukup baik dilihat dari kegiatan pendataan penduduk nonpermanen yang sampai saat ini sudah terlaksanakan tetapi belum berjalan secara optimal.

(b) Interpertasi

Interpretation: the translation of program language (often contaned in a statute) into acceptable and feasible plans and directivesJones dalam Joko Widodo (2007: 89). (Interprestasi: aktivitas interprestasi (penjelasan) substansi dari suatu kebijakan dalam bahasa yang lebih operasional dan mudah dipahami sehingga dapat dilaksanakan dan diterima oleh para pelaku dan sasaran kebijakan).

Deskripsi dimensi interprestasi adalah bagaimana menjelaskan tentang tujuan, sasaran, prosedur dan kesesuaian rencana dengan tindakan dalam melakukan pekerjaan atau program kerja berdasarkan peraturan perundang-undangan yang berlaku sehingga tercapai suatu target yang telah ditentukan. Deskripsi dimensi organisasi adalah 
bagaimana cara menafsirkan tugas dan kewenangan untuk menjalankan kebijakan tentang pendataan penduduk non permanen di Kabupaten Bangka.

Kejelasan tujuan dalam deskripsi dimensi interprestasi adalah mengenai tujuan yang ingin dijelaskan dari implementasi kebijakan pendataan penduduk non permanen itu sendiri dapat tercapai dengan maksimal. Kejelasan sasaran mengenai target atau kehendak yang ingin dijelaskan dari implementasi kebijakan pendataan penduduk non permanen. Kejelasan prosedur mengenai prosedur yang ingin dijelaskan dari implementasi kebijakan pendataan penduduk non permanen agar tidak bertentangan dengan peraturan perundangundangan yang berlaku. Sedangkan untuk kesesuaian rencana adalah masalah rencana awal suatu tindakan dalam melakukan kegiatan apakah sudah sesuai dengan kebijakan pemerintah yang telah berlaku.

Pada dimensi interpretasi, peneliti menemukan bahwa pemahaman dari para pelaksana kebijakan pendataan penduduk nonpermanen di Kabupaten Bangka sudah cukup baik dalam memahami akan tujuan dan sasaran kebijakan. Akan tetapi para pelaksana belum konsisten dalam menjalankan tugas dan fungsinya. Hal tersebut dikarenakan belum semua aturan yang telah ditetapkan berjalan sesuai dengan yang diharapkan seperti belum optimalnya dalam melakukan sosialisasi.

(c) Aplikasi

Application: the routine provision of service, paymens, or other agree upon objectives of instrumentsCharle O. Jones dalam Joko Widodo (2007: 89). (Aplikasi: aktivitas penyediaan pelayanan secara rutin, pembayaran atau lainnya sesuai dengan tujuan dan sarana kebijakan yang ada).

Dimensi aplikasi adalah penerapan tentang isi kebijakan pemerintah harus dilaksanakan agar tercapai apa yang menjadi kehendak dari kebijakan yang tersebut. Deskripsi dimensi aplikasi adalah bagaimana cara menerapkan kebijakan tersebut baik dari ketentuan rutin dari pelayanan, pembayaran atau lainnya disesuaikan dengan tujuan dan sarana kebijakan yang ada berdasarkan peraturan perundang-undangan yang berlaku sehingga tercapai sesuai target yang telah ditentukan. Dimensi aplikasi dapat dilihat dengan bagaimana cara menerapkan isi kebijakan tersebut sesuai dengan tugas dan kewenangan untuk menjalankan kebijakan tentang pendataan penduduk non permanen di Kabupaten Bangka. Deskripsi dimensi aplikasi di sini terdiri dari beberapa indikator diantaranya aktivitas penyediaan pelayanan secara rutin, pembayaran atau lainnya sesuai dengan tujuan dan sarana kebijakan yang ada.

Penyediaan pelayanan kebijakan disini adalah bagaimana cara menangani dalam memberikan pelayanan tentang kebijakan yang dijelaskan dalam kebijakan pendataan penduduk non permanen agar tujuan tersebut dapat tercapai dengan maksimal dan tidak bertentangan dengan peraturan perundang-undangan yang berlaku. Indikator ini digunakan peneliti untuk melihat deskripsi aplikasi dalam implementasi kebijakan pendataan penduduk non permanen di Kabupaten Bangka.

\section{Bentuk Surat Keterangan Penduduk Non Permanen}

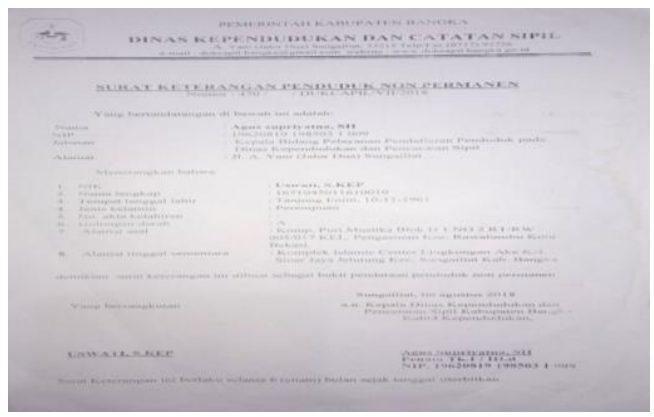

Sumber: Dindukpencapil Kabupaten Bangka

Berdasarkan hasil wawancara peneliti dengan berbagai informan (narasmuber) pada dimensi aplikasi ini dapat disimpulkan bahwa dalam pelaksanannya aparatur pelaksana sudah berpedoman pada peraturan yang ada, karena dalam pendataan penduduk nonpermanen ini tidak ada pelayanan khusus yang diberikan kepada penduduk pendatang melainkan hanya sebatas pembuatan surat keterangan sesuai dengan keperluan penduduk pendatang tersebut.

\section{Faktor-Faktor Yang Mempengaruhi Implementasi Kebijakan Pendataan Penduduk Non Permanen di Kabupaten Bangka}


Implementasi kebijakan tentang pendataan penduduk non permanen yang di atur dalam Peraturan Menteri Dalam Negeri Nomor 14 Tahun 2015 tentang pedoman pendataan penduduk non permanen tidak dapat diimplementasikan dengan baik, hal ini disebabkan oleh beberapa faktor yang merupakan syaratsyarat penting guna mengkaji dan meneliti berhasil tidaknya implementasi kebijakan tersebut. Faktor-faktor yang mempengaruhi implementasi kebijakan dalam penelitian ini, peneliti menggunakan teori yang dikemukakan oleh Edward III dalam Riant Nugroho (2017: 744), merumuskan empat faktor yang merupakan syaratsyarat penting guna mengkaji dan meneliti berhasil tidaknya implementasi kebijakan. Keempat faktor itu adalah sebagai berikut:

(1) Komunikasi berkenaan dengan bagaimana kebijakan dikomunikasikan kepada organisasi dan/ atau publik dan sikap serta tanggapan dari para pihak yang terlibat.

(2) Sumber daya berkenaan dengan ketersediaan sumberdaya pendukung, khususnya sumber daya manusia, di mana hal ini berkenaan dengan kecakapan dari pelaksana kebijakan publik untuk carry out kebijakan secara efektif.

(3) Disposisi berkenaan dengan kesediaan dan komitmen untuk melaksankan kebijakan.

(4) Struktur birokrasi berkenaan dengan kesesuaian organisasi birokrasi yang menjadi penyelenggara implementasi kebijakan publik. Tantangannya adalah bagaimana agar tidak terjadi bureaucratic fragmentation, karena ini menjadikan proses implementasi menjadi jauh dari efektif.

Hasil penelitian ini merupakan rangkuman dari observasi dan wawancara dengan berbagai pihak tentang pelaksanaan pendataan penduduk nonpermanen di Kabupaten Bangka. Data penelitian ini berupa hasil observasi dan wawancara dengan aparatur di Dinas Kependudukan dan Pencatatan Sipil Kabupaten Bangka, aparatur di kecamatan, aparatur di kelurahan, kepala lingkungan dan penduduk pendatang yang melaksanakan pendataan penduduk nonpermanen, data-data serta dokumentasi yang relevan dengan penelitian inidengan menggunakan teori dari Edward III dalam Riant Nugroho (2017: 774) yakni Komunikasi, Sumber Daya, Disposisi dan Struktur Organisasi.

\section{(1) Komunikasi}

Salah satu unsur yang dapat mempengaruhi keberhasilan pelaksanaan sebuah kebijakan menurut Edward III dalam Riant Nugroho (2017: 747) adalah komunikasi,komunikasi berkenaan dengan bagaimana kebijakan dikomunikasikan kepada organisasi dan/ atau publik dan sikap serta tanggapan dari para pihak yang terlibat. Sementara itu, komunikasi kebijakan berarti merupakan proses penyampaian informasi kebijakan dari pembuat kebijakan (policy makers) kepada pelaksana kebijakan (policy implementors). Komunikasi dalam konteks penelitian ini digunakan agar pelaksanaan kebijakan pendataan penduduk non permanen ini dapat berjalan dengan baik. Komunikasi ini dilakukan oleh aparatur Dinas Kependudukan dan Pencatatan Sipil Kabupaten Bangka untuk melakukan sosialisasi kepada perangkat yang ada dibawah tentang adanya peraturan administrasi kependudukan baru yaitu Peraturan Menteri Dalam Negeri Nomor 14 Tahun 2015 tentang Pedoman Pendataan Penduduk Non Permanen agar aparatur dapat berkomunikasi langsung terhadap pelaksana kebijakan ini.

Komunikasi dalam implementasi kebijakan mencakup beberapa dimensi penting yaitu tranformasi informasi (transimission), kejelasan informasi (clarity) dan konsistensi informasi (consistency). Dimensi tranformasi menghendaki agar informasi tidak hanya disampaikan kepada pelaksana kebijakan tetapi juga kepada kelompok sasaran dan pihak yang terkait. Dimensi kejelasan menghendaki agar informasi yang jelas dan mudah dipahami, selain itu untuk menghindari kesalahan interpretasi dari pelaksana kebijakan, kelompok sasaran maupun pihak yang terkait dalam implementasi kebijakan. Sedangkan dimensi konsistensi menghendaki agar informasi yang disampaikan harus konsisten sehingga tidak menimbulkan kebingungan pelaksana kebijakan, kelompok sasaran maupun pihak terkait.

Transmisi(transmission) merupakan dimensi utama dalam hal komunikasi pelaksana kebijakan. 
Penyaluran komunikasi yang baik akan dapat menghasilkan suatu implementasi yang baik pula. Transmisi dalam implementasi kebijakan pendataan penduduk non permanen di Kabupaten Bangka berupa penyampaian atau pengiriman informasi dari pemerintah kepada instansi pelaksana kebijakan. Transmisi pada kebijakan pendataan penduduk non permanen dilakukan oleh Dinas Kependudukan dan Pencatatan Sipil Kabupaten Bangka.Dalam penelitian ini penyampaian informasi bukan hanya disampaikan kepada para pelaksana saja tetapi yang tidak kalah pentingnya adalah harus disampaikan kepada masyarakat sebagai sasaran kebijakan agar pentingnya suatu kebijakan dapat dilaksanakan dengan baiksehingga dapat diketahui oleh semua pihak yang berkepentingan termasuk masyarakat.

Dimensi kedua adalah kejelasan(clarity). Dimensi kejelasan komunikasi juga merupakan elemen yang penting. Kejelasan komunikasi menentukan akan keberhasilan implementasi sebuah kebijakan publik. Jika kebijakan-kebijakan diimplementasikan sebagaimana yang diinginkan, maka petunjuk-petunjuk pelaksanaan tidak hanya harus diterima oleh para pelaksana kebijakan, tetapi juga komunikasi kebijakan tersebut harus jelas. Ketidakjelasan pesan komunikasi yang disampaikan berkenaan dengan implementasi kebijakan akan mendorong terjadinya kesalahpahaman bahkan mungkin bertentangan dengan makna pesan awal. Kejelasan komunikasi dalam implementasi kebijakan pendataan penduduk non permanen, terdiri dari penyampaian informasi oleh Dinas Kependudukan dan Pencatatan SipilKabupaten Bangka. Keterbukaan mengenai informasi pendataan penduduk non permanen dilakukan dengan tujuan agar seluruh pelaksana pendataan mengetahui secara jelas informasi apa saja yang telah disampaikan oleh Dinas Kependudukan dan Pencatatan SipilKabupaten Bangka. Apabila ada masalah mengenai pendataan penduduk non permanen atau ada informasi terbaru tentang pendataan penduduk non permanen, maka Dinas Kependudukan dan Pencatatan Sipil langsung menguhubungi ke tingkat yang bawah seperti Kecamatan, Kelurahan sehingga dari Kelurahan menyampaikan ke Kepala Lingkungan maupun RT setempat, untuk memberikan informasi tersebutkepada masyarakat.

Sedangkan untuk konsistensi (consistency) adalah pentingnya ketetapan yang tidak berubah-ubah mengenai informasi yang disampaikan tentang implementasi kebijakan pendataan penduduk non permanen di Kabupaten Bangka. Konsistensi ini sangat diperlukan agar tidak terjadi kesimpangsiuran di dalam masyarakat mengenai implementasi kebijakan pendataan penduduk non permanen di Kabupaten Bangka, siapa saja yang boleh mendapatkan surat keterangan penduduk non permanen, apa saja persyaratannya, serta bagaimana pelaksanaan di lapangan sesuai dengan peraturan perundang-undangan yang berlaku. Ini semua harus ada konsistensi agar masyarakat menjadi jelas tidak bertanya-tanya lagi mengenai kebijakan pendataan penduduk non permanen di Kabupaten Bangka.

\section{Sosialisasi Kebijakan Administrasi Kependudukan}

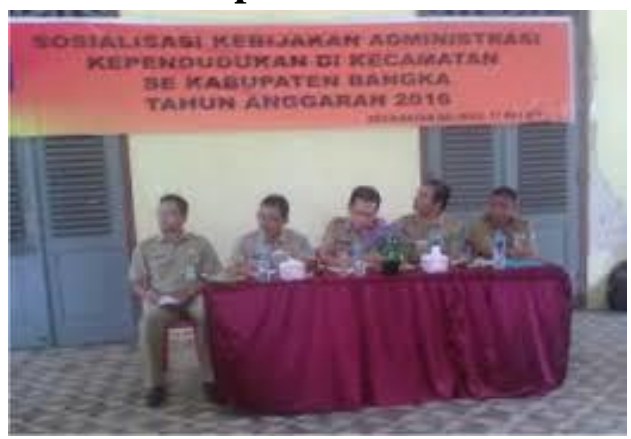

Sumber : Dindukpencapil Kabupaten Bangka

Untuk dimensi penyampaian atau penyebaran informasi yang ada dalam indikator komunikasi mengenai indikator-indikator yang berhubungan dengan implementasi kebijakan pendataan penduduk non permanen di Kabupaten Bangka dapat dikatakan bahwa untuk melakukan penyampaian atau penyebaran informasi bukan hanya tugas dari Dinas Kependudukan dan Pencatatan Sipil Kabupaten Bangka, tetapi juga tugas Kecamatan, Kelurahan hingga tingkat yang lebih bawah seperti Kepala Lingkungan dan RT.

Dari observasi yang telah peneliti lakukan di lapangan, untuk indikator penyampaian atau penyebaran informasi terkait implementasi kebijakan pendataan penduduk non permanen di Kabupaten Bangka oleh Dinas Kependudukan dan 
Pencatatan Sipil Kabupaten Bangka terhadap pelaksana di tingkat bawah, belum dilakukan dengan baik karena seperti yang telah peneliti temukan dilapangan bahwa yang melaksanakan pendataan penduduk non permanen di Kabupaten Bangka hanyaada satu kelurahan yaitu Kelurahan SrimenantiKecamatan Sungailiat.

Rekapitulasi Penduduk Non Permanen Kelurahan Srimenanti Tahun 2017

\begin{tabular}{|c|c|c|c|c|}
\hline $\begin{array}{l}\mathrm{N} \\
\mathrm{O} .\end{array}$ & NAMA & $\begin{array}{l}\text { ALAMAT } \\
\text { SEMULA }\end{array}$ & $\begin{array}{c}\text { ALAMA } \\
\text { T } \\
\text { KONTR } \\
\text { AKAN }\end{array}$ & $\begin{array}{c}\text { KEPER } \\
\text { LUAN }\end{array}$ \\
\hline 1 & $\begin{array}{c}\text { NASIP } \\
\text { SUPRIY } \\
\text { ADI }\end{array}$ & $\begin{array}{c}\text { Balepanjan } \\
\text { g } \\
\text { Kec. Jati } \\
\text { Purno }\end{array}$ & $\begin{array}{c}\text { Jl. } \\
\text { Kartini } \\
\text { Sidodadi } \\
\text { RT.004 }\end{array}$ & $\begin{array}{c}\text { BEKER } \\
\text { JA }\end{array}$ \\
\hline 2 & $\begin{array}{c}\text { ALI } \\
\text { USMAN }\end{array}$ & $\begin{array}{c}\text { Salebu } \\
\text { Kec. } \\
\text { Majenang }\end{array}$ & $\begin{array}{c}\text { Jl. } \\
\text { Kartini } \\
\text { Sidodadi } \\
\text { RT.004 }\end{array}$ & $\begin{array}{c}\text { PEDAG } \\
\text { ANG }\end{array}$ \\
\hline 3 & $\begin{array}{l}\text { BARDI } \\
\text { YONO }\end{array}$ & $\begin{array}{c}\text { Sumberejo } \\
\text { Kec. } \\
\text { Gondangre } \\
\text { jo } \\
\end{array}$ & $\begin{array}{c}\text { Jl. } \\
\text { Kartini } \\
\text { Sidodadi } \\
\text { RT.004 }\end{array}$ & $\begin{array}{c}\text { BEKER } \\
\text { JA }\end{array}$ \\
\hline 4 & $\begin{array}{c}\text { SAEFUL } \\
\text { BAKHR } \\
\text { I }\end{array}$ & $\begin{array}{c}\text { Blok } 2 \\
\text { Kec. } \\
\text { Panguraga } \\
\text { n }\end{array}$ & $\begin{array}{l}\text { Lingk. } \\
\text { Sidodadi } \\
\text { RT.005 }\end{array}$ & $\begin{array}{c}\text { BEKER } \\
\text { JA }\end{array}$ \\
\hline 5 & $\begin{array}{c}\text { PARMA } \\
\mathrm{N}\end{array}$ & $\begin{array}{c}\text { Kembang } \\
\text { Kec. Jati } \\
\text { Purno }\end{array}$ & $\begin{array}{l}\text { Lingk. } \\
\text { Sidodadi } \\
\text { RT.002 }\end{array}$ & $\begin{array}{c}\text { BEKER } \\
\text { JA }\end{array}$ \\
\hline 6 & KASTO & $\begin{array}{c}\text { Jl. Tunggul } \\
\text { Ametung } \\
\text { Singosari }\end{array}$ & $\begin{array}{c}\text { Lingk. } \\
\text { Sidodadi } \\
\text { RT.002 }\end{array}$ & $\begin{array}{c}\text { BEKER } \\
\text { JA }\end{array}$ \\
\hline 7 & $\begin{array}{c}\text { MARSI } \\
\text { DI }\end{array}$ & $\begin{array}{c}\text { Dusun } \\
\text { Timur } \\
\text { Jalan Kec. } \\
\text { Kokop }\end{array}$ & $\begin{array}{l}\text { Lingk. } \\
\text { Sidodadi } \\
\text { RT.005 }\end{array}$ & $\begin{array}{c}\text { BEKER } \\
\text { JA }\end{array}$ \\
\hline 8 & $\begin{array}{l}\text { AHMAD } \\
\text { FAUZA }\end{array}$ & $\begin{array}{l}\text { Toroy } \\
\text { Kec. } \\
\text { Kokop }\end{array}$ & $\begin{array}{c}\text { Lingk. } \\
\text { Sidodadi } \\
\text { RT.005 }\end{array}$ & $\begin{array}{c}\text { BEKER } \\
\text { JA }\end{array}$ \\
\hline
\end{tabular}

\begin{tabular}{|c|c|c|c|c|}
\hline & $\mathrm{N}$ & & & \\
\hline 9 & $\begin{array}{c}\text { AHMAD } \\
\text { I }\end{array}$ & $\begin{array}{c}\text { Dusun } \\
\text { Olor } \\
\text { Kec. } \\
\text { Banyuates }\end{array}$ & $\begin{array}{l}\text { Lingk. } \\
\text { Sidodadi } \\
\text { RT.005 }\end{array}$ & $\begin{array}{c}\text { BEKER } \\
\text { JA }\end{array}$ \\
\hline 10 & $\begin{array}{c}\text { M. } \\
\text { YUNUS }\end{array}$ & $\begin{array}{c}\text { Kel. } \\
\text { Kubang } \\
\text { Jati } \\
\text { Kec.Ketan } \\
\text { ggungan }\end{array}$ & $\begin{array}{l}\text { Lingk. } \\
\text { Sidodadi } \\
\text { RT.005 }\end{array}$ & $\begin{array}{c}\text { PEDAG } \\
\text { ANG }\end{array}$ \\
\hline 11 & $\begin{array}{c}\text { TARSO } \\
\text { MA }\end{array}$ & $\begin{array}{c}\text { Kel. } \\
\text { Kubang } \\
\text { Jati } \\
\text { Kec.Ketan } \\
\text { ggungan }\end{array}$ & $\begin{array}{l}\text { Lingk. } \\
\text { Sidodadi } \\
\text { RT.005 }\end{array}$ & $\begin{array}{c}\text { BEKER } \\
\text { JA }\end{array}$ \\
\hline 12 & $\begin{array}{c}\text { AHMAD } \\
\text { SOLEH }\end{array}$ & $\begin{array}{c}\text { Krakahan } \\
\text { Kec. } \\
\text { Tanjung }\end{array}$ & $\begin{array}{l}\text { Lingk. } \\
\text { Sidodadi } \\
\text { RT.005 }\end{array}$ & $\begin{array}{c}\text { BEKER } \\
\text { JA }\end{array}$ \\
\hline 13 & $\begin{array}{c}\text { NURYA } \\
\text { DI }\end{array}$ & $\begin{array}{c}\text { Krakahan } \\
\text { Kec. } \\
\text { Tanjung }\end{array}$ & $\begin{array}{l}\text { Lingk. } \\
\text { Sidodadi } \\
\text { RT.005 }\end{array}$ & $\begin{array}{c}\text { BEKER } \\
\text { JA }\end{array}$ \\
\hline 14 & NARJO & $\begin{array}{c}\text { Besi } \\
\text { Kec. } \\
\text { Jatipurno }\end{array}$ & $\begin{array}{l}\text { Lingk. } \\
\text { Sidodai } \\
\text { RT.005 }\end{array}$ & $\begin{array}{c}\text { BEKER } \\
\text { JA }\end{array}$ \\
\hline 15 & $\begin{array}{c}\text { IR. } \\
\text { AGUS } \\
\text { PRASET } \\
\text { YA }\end{array}$ & $\begin{array}{c}\text { Wirobrajan } \\
\text { WB.002/36 } \\
1\end{array}$ & $\begin{array}{l}\text { Lingk. } \\
\text { Sidodadi } \\
\text { RT.005 }\end{array}$ & $\begin{array}{c}\text { BEKER } \\
\text { JA }\end{array}$ \\
\hline 16 & $\begin{array}{c}\text { EVAN } \\
\text { SETIAN } \\
\text { SYAH }\end{array}$ & $\begin{array}{c}\text { Perum. } \\
\text { Tegal Rejo } \\
\text { Yogyakarta }\end{array}$ & $\begin{array}{l}\text { Lingk. } \\
\text { Sidodadi } \\
\text { RT. } 005\end{array}$ & $\begin{array}{c}\text { KARYA } \\
\text { WAN } \\
\text { SWAST } \\
\text { A }\end{array}$ \\
\hline 17 & $\begin{array}{l}\text { SAMSU } \\
\text { L HADI }\end{array}$ & $\begin{array}{c}\text { Blok } 2 \text { Kel. } \\
\text { Panguraga } \\
n\end{array}$ & $\begin{array}{l}\text { Lingk. } \\
\text { Sidodadi } \\
\text { RT.005 }\end{array}$ & $\begin{array}{c}\text { PEDAG } \\
\text { ANG }\end{array}$ \\
\hline 18 & FAIZAT & $\begin{array}{c}\text { Lingkunga } \\
\text { n I }\end{array}$ & $\begin{array}{c}\text { Lingk. } \\
\text { Sidodadi }\end{array}$ & - \\
\hline
\end{tabular}




\begin{tabular}{|c|c|c|c|c|}
\hline & $\begin{array}{c}\text { UL } \\
\text { KHOIRI } \\
\text { YAN }\end{array}$ & $\begin{array}{c}\text { Kel.Bandar } \\
\text { Jaya }\end{array}$ & RT.005 & \\
\hline 19 & $\begin{array}{c}\text { SUMAR } \\
\text { NO }\end{array}$ & $\begin{array}{c}\text { Dk. Jetis } \\
\text { Kec. } \\
\text { Tawangsari }\end{array}$ & $\begin{array}{c}\text { Lingk. } \\
\text { Sidodadi } \\
\text { RT.003 }\end{array}$ & BHL \\
\hline 20 & $\begin{array}{c}\text { ARIYA } \\
\text { NTO }\end{array}$ & $\begin{array}{c}\text { Ngeledok } \\
\text { Kel. }\end{array}$ & $\begin{array}{c}\text { Lingk. } \\
\text { Sidodadi } \\
\text { JT. 003 }\end{array}$ & BHL \\
& & Jatikuwung & RT. \\
\hline
\end{tabular}

Sumber: Data diolah peneliti berdasarkan rekapitulasi formulir laporan penduduk non permanen Kelurahan Srimenanti Kecamatan Sungailiat

Berdasarkan Tabel diatas, dapat dilihat bahwa penduduk non permanen merupakan penduduk pendatang yang datang dari luar daerah Kabupaten Bangka, rata-rata penduduknya banyak dari pulau Jawa. Mereka datang ke Kabupaten Bangka untuk mencari pekerjaan, ada yang berdagangdan menjadi tukang bangunan.Ada yang membawa anggota keluarganya ada juga yang hanya datang sendiri.

Sebagaimana yang kita ketahui bersama bahwa salah satu indikator yang berpwengaruh dalam implementasi kebijakan pendataan penduduk non permanen adalah komunikasi. Namun sebelum itu, perlu diketahui bahwa implementasi akan berjalan efektif apabila ukuran-ukuran dan tujuantujuan kebijakan dipahami oleh individu-individu yang bertanggungjawab dalam pencapaian tujuan kebijakan. Kejelasan ukuran dan tujuan kebijakan dengan demikian perlu dikomunikasikan secara tepat dengan para pelaksana. Hal inilah yang tidak berjalan secara efektif dalam pelaksanaan kebijakan penduduk non permanen di Kabupaten Bangka dimana para aktor-aktor yang terlibat langsung didalam pelaksanaan kebiijakan tidak berperan aktif didalam pelaksanaan kebijakan sehingga komunikasi tidak berjalan baik antara pelaksana kebijakan sesuai dengan tuntutan kebijakan yang dikeluarkan.

Dari hasil pengamatan langsung di lapangan yang dilakukan oleh peneliti memperlihatkan bahwa kurangnya konsistensi atau keseragaman dari pada ukuran dasar dan tujuan dari kebijakan pendataan penduduk nonpermanen yang dikomunikasikan dengan kurang begitu baik di Kabupaten Bangka sehingga implementor seakan-akan kurang begitu mengetahui secara tepat ukuran maupun tujuan dari pada kebijakan pendataan yang hendak diterapkan atau dilaksanakan di Kabupaten Bangka. Sebagaimana kita ketahui bersama bahwa komunikasi dalam organisasi merupakan suatu proses yang amat kompleks dan rumit. Inilah yang menyebabkan sumber informasi yang berbeda sehingga akan melahirkan interpretasi yang berbeda pula.

Selanjutnya masih menyangkut permasalahan indikator komunikasi yang kurang efektif sehingga kebijakan pendataan penduduk non permanen yang merupakan terobosan dalam administrasi kependudukan tidak berjalan sesuai dengan tuntutan peraturan yang berlaku diwilayah Kabupaten Bangka yaitu kurangnya komunikasi antara implementor dalam hal ini aparat pelaksana kebijakan yaitu Dinas Kependudukan dan Pencatatan Sipil dengan lembaga yang tingkatannya lebih bawah seperti RT/RW, Kepala Lingkungan, Kepala Desa/Lurah di Kabupaten Bangka. Dimana komunikasi disini memegang peranan penting sebab para implemantor harus mengadukan permasalahanpermasalan yang meraka hadapi ketika ingin atau hendak melaksanakan kebijakan pendataan penduduk ini di Kabupaten Bangka.

Kemudian fakta yang terjadi di lapangan yang ditemukan oleh penulis yaitu tidak adanya komunikasi yang terjalin antara implementor dengan sasaran kebijakan atau dengan kata lain masyarakat maupun dengan aparat pelaksana ditingkat bawah. Berikut merupakan kutipan wawancara langsung yang dilakukan oleh penulis dengan salah seorang masyarakat yang merupakan penduduk pendatang.

Berdasarkan hasil wawancara peneliti dengan informan(narasumber) dan didukung dengan berbagai fakta dilapangan menunjukkan secara jelas bahwa sampai saat ini keberadaan dari pada kebijakan pendataan penduduk non permanen di Kabupaten Bangka secara mayoritas masyarakat belum mengetahuinya. Hal ini disebabkan karena kurangnya sosialisasi antara implementor dari 
tingkat atas ke tingkat bawah hingga ke masyarakat. Fakta ini juga dapat dilihat dari pelaksanaannya, karena yang peneliti temukan di lapangan hanya Kelurahan Sri Menanti Kecamatan Sungailiat yang melaksanakan pendataan penduduk non permanen di Kabupaten Bangka. Maka dapat disimpukan hal ini belum sesuai dengan apa yang dikatakan Edward III bahwa komunikasi suatu kebijakan harus konsisten dan jelas untuk ditetapkan dan dijalankan, masih kurangnya komunikasi yang diberikan oleh aparatur pelaksana dari tingkat atas ke tingkat bawah maupun dari tingkat bawah kepada masyarakat.

\section{(2) Sumber Daya}

Sumber daya menjadi salah satu faktor penting dalam implementasi kebijakan publik. Sumber daya meliputi sumber daya manusia, sumber daya anggaran, dan sumber daya fasilitas. Sumber daya menusia berkenaan dengan kecakapan pelaksana kebijakan publik untuk mengimplementasikan kebijakan secara efektif.Sumber daya (resources) di sini menyangkut empat komponen yaitu staf (staff) yang cukup (jumlah dan mutu), informasi (information) yang dibutuhkan guna mengambil keputusan, kewenangan (authority) yang cukup guna melaksanakan tugas dan tanggung jawabnya serta fasilitas (facilities) yang dibutuhkan dalam implementasi kebijakan.

Deskripsi sumber daya (resources) di sini merupakan sarana yang bisa mencapai suatu tujuan dari kebijakan pemerintah dengan maksimal yang terdiri dari empat (4) yaitu: staf (staff) yang cukup (jumlah dan mutu), infromasi (authorithy) yang cukup guna melaksanakan tugas dan tanggung jawabnya serta pelaksanaan tentang implementasi kebijakan pendataan penduduk non permanen di Kabupaten Bangka, maka harus memperhatikan dan memiliki staf (staff) yang cukup (jumlah dan mutu), informasi (information) yang dibutuhkan guna mengambil keputusan, kewenangan (authority) yang cukup guna melaksanakan tugas dan tanggung jawabnya serta fasilitas (facilities) yang dibutuhkan dalam implementasi kebijakan. Indikator-indikator inilah yang akan mencapai tujuan dari sumber daya (resources) berhasil atau tidaknya sangat tergantung kepada semua indikator tersebut.

Informasi (information) yang dibutuhkan guna mengambil keputusan dalam mengimplementasikan kebijakan tentang pendataan penduduk non permanen di Kabupaten Bangka. Indikator ini digunakan peneliti untuk melihat faktor sumber daya (resources) yang berhubungan dengan implementasi kebijakan pendataan penduduk non permanen di Kabupaten Bangka.

Kewenangan (authority) yang cukup melaksanakan tugas dan tanggung jawabnya adalah siapa yang memiliki kewenangan penuh dalam rangka melaksanakan tugas dan tanggung jawab khusunya untuk mengimplementasikan kebijakan tentang pendataan penduduk non permanen di Kabupaten Bangka. Indikator ini digunakan peneliti untuk melihat sumber daya (resources) yang berhubungan dengan implementasi kebijakan pendataan penduduk non permanen di Kabupaten Bangka.

Fasilitas (facilities) yang dibutuhkan dalam implementasi kebijakan di sini yang dimaksudkan adalah fasilitas yang dibutuhkan dalam menunjang proses pelaksanaan suatu kebijakan. Dalam hal ini fasilitas yang dibutuhkan adalah fasilitas dalam rangka untuk mengimplementasikan kebijakan tentang pendataan penduduk non permanen di Kabupaten Bangka. Dimensi ini digunakan peneliti untuk melihat indikator sumber daya (resources) yang berhubungan dengan implementasi kebijakan pendataan penduduk non permanen di Kabupaten Bangka.

\section{Formulir Pendataan Penduduk Non Permanen}

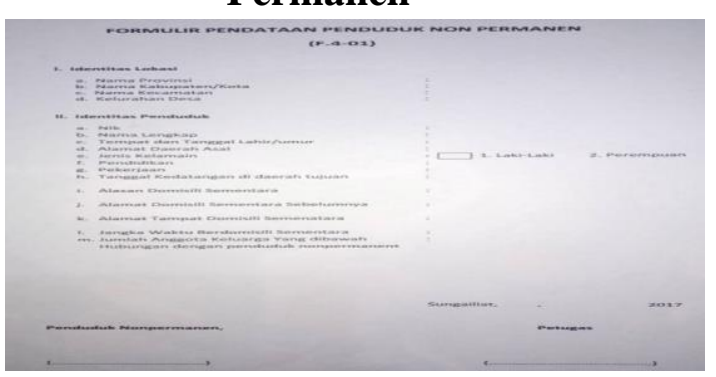

Sumber : Kelurahan Sri Menanti

Sumber daya manusia merupakan sumber daya yang paling penting dalam pelaksanaan kebijakan. Sumber daya yang dipilih berdasarkan asas efektif dan efisien dapat menjadi salah satu 
faktor pendorong agar pelaksanaan kebijakan dapat berjalan dengan baik. Oleh karena itu, implementasi kebijakan pendataan penduduk non permanen membutuhkan sumber daya yang cukup dan mampu untuk menguasai di dalam bidangnya dalam melaksanakan kebijakan, sumber daya manusia yang dimaksud adalah aparatur pelaksana kebijakan pendataan penduduk non permanen di Kabupaten Bangka.

Implementasi kebijakan tidak akan berhasil tanpa adanya dukungan dari sumber daya manusia yang cukup kualitas dan kuantitasnya. Kualitas sumber daya manusia berkaitan dengan keterampilan, dedikasi, profesionalitas, dan kompetensi di bidangnya, sedangkan kuatitas berkaitan dengan jumlah sumber daya manusia apakah sudah cukup untuk melingkupi seluruh kelompok sasaran. Sumber daya manusia sangat berpengaruh terhadap keberhasilan implementasi, sebab tanpa sumber daya manusia yang kehandalan sumber daya manusia, implementasi kebijakan akan berjalan lambat.

Sumber daya manusia merupakan faktor yang mendukung dalam Implementasi Kebijakan Pendataan Penduduk Nonpermanen di Kabupaten Bangka, baik secara administratif maupun secara teknis. Sumber daya Manusia dalam kebijakan pendataan penduduk non permanen di Kabupaten Bangka, yaitu Dinas Kependudukan dan Pencatatan Sipil Kabupaten Bangka. Pegawai yang bertugas dalam implementasi kebijakan pendataan penduduk nonpermanen di Kabupaten Bangka adalah :

- Kepala Bidang Pendaftaran Penduduk

- Kepala Seksi Pendataan Penduduk

- Kepala Seksi Pelayanan Umum

Kecamatan/Kelurahan

- Kepala Lingkungan/RT setempat

Sumber daya manusia implementornya belum memadai dalam menjalankan proses-proses yang seharusnya dilaksanakan guna menyampaikan isi dari kebijakan. Kekurangan sumber daya manusia menjadi kendala dalam upaya implementor menyampaikan keluaran kebijakan kepada kelompok sasaran, dimana terlihat bahwa implementor kekurangan sumber daya manusia dalam melaksanakan tugas dan fungsinya.

(3) Disposisi
Menurut Edward III dalam Riant Nugroho (2017: 747) disposisi berkenaan dengan kesediaan dan komitmen untuk melaksanakan kebijakan, respon implementor terhadap kebijakan serta kesadaran pelaksana atas petunjuk atau arahan pelaksana untuk merespon kebijakan kearah penerimaan atau penolakan. Kecenderungan dari para pelaksana kebijakan merupakan faktor ketiga yang mempunyai konsenkuensi-konsenkuensi penting bagi implementasi kebijakan yang efektif. Jika para pelaksana bersikap baik terhadap suatu kebijakan tertentu dan hal ini berarti adanya dukungan, kemungkinan besar mereka melaksanakan kebijakan sebagaimana yang diinginkan oleh para pembuatan keputusan awal. Demikian pula sebaliknya, bila tingkah laku atau perspektif-persepektif para pelaksanaberbeda dengan para pembuat keputusan, maka proses pelaksanaan suatu kebijakan menadi semakin sulit.

Disposisi atau sikap dari pelaksana kebijakan adalah faktor yang penting dalam pendekatan mengenai pelaksanaan kebijakan publik. Jika pelaksana suatu kebijakan ingin efektif, maka para pelaksana kebijakan tidak hanya harus mengetahui apa yang akan dilakukan tetapi juga harus memiliki kemampuan untuk melaksanakannya. Kecenderungan perilaku atau karakteristik dari pelaksana kebijakan berperan penting untuk mewujudkan implementasi kebijakan yang sesuai dengan tujuan atau sasaran.

Karakter penting yang harus dimiliki oleh pelaksana kebijakan misalnya kejujuran dan komitmen yang tinggi. Kejujuran mengarahkan implementor untuk tetap berada dalam asa kebijakanyang telah digariskan, sedangkan komitmen yang tinggi dari pelaksana kebijakan akan membuat mereka selalu antusias dalam melaksanakan tugas, wewenang, fungsi, dan tanggung jawab sesuai dengan peraturan yang telah ditetapkan. Sikap dari pelaksana kebijakan akan sangat berpengaruh dalam implementasi kebijakan. Apabila implementator memiliki sikap yang baik maka dia akan dapat menjalankan kebijakan dengan baik seperti apa yang diinginkan oleh pembuat kebijakan, sebaliknya apabila sikapnya tidak mendukung maka implementasi tidak akan terlaksana dengan baik. 
Watak dan karakteristik atau sikap yang dimiliki oleh implementor seperti komitmen, kejujuran, sifat demokratis. Apabila implementor memiliki disposisi yang baik, maka dia akan dapat menjalankan kebijakan dengan baik seperti apa yang diinginkan oleh pembuat kebijakan. Ketika implementor memiliki sifat atau perspektif yang berbeda dengan pembuat kebijakan, maka proses implementasi kebijakan juga menjadi tidak efektif.

Dari hasil wawancara kepada narasumber di atas dapat disimpulkan bahwa untuk indikator disposisi dari faktor-faktor yang mempengaruhi implementasi kebijakan pendataan penduduk non permanen adalah pelaksana kebijakan maupun masyarakat sangat mendukung dengan adanya pelaksanaan kebijakan pendataan penduduk non permanen di Kabupaten Bangka alasannya kebijakan ini dapat mempermudah dalam proses tercapainya administrasi kependudukan dan untuk melihat mobilitas penduduk. Dari hasil wawancara dan observasi dilapangan, maka dapat disimpulkan komitmen aparatur pelaksana dalam implementasi kebijakan pendataan penduduk non permanen di Kabupaten Bangka dapat dikatakan sudah cukup baik.

\section{(4) Struktur Birokrasi}

Struktur birokrasi memiliki pengaruh yang signifikan terhadap implementasi kebijakan. Aspek struktur birokrasi ini melingkupi dua hal yaitu mekanisme dan struktur birokrasi itu sendiri. Aspek pertama adalah mekanisme, dalam implementasi kebijakan biasanya sudah dibuat Standart Operational Procedure (SOP). SOP menjadi pedoman bagi setiap implementator dalam bertindak agar dalam pelaksanaan kebijakan tidak melenceng dari tujuan dan sasaran kebijakan. Aspek kedua adalah struktur birokrasi, struktur birokrasi yang terlalu panjang dan terfragmentasi akan cenderung melemahkan pengawasan dan menyebabkan prosedur birokrasi yang rumit dan kompleks yang selanjutnya akan menyebabkan aktivitas organisasi menjadi tidak fleksibel.

Menurut Edward III dalam Riant Nugroho (2017: 747), menjelaskan bahwa struktur birokrasi berkenaan dengan kesesuaian organisasi birokrasi yang menjadi penyelenggara implentasi kebijakan publik. Tantangannya adalah bagaimana agar tidak terjadi bureaucratic fragmentation karena struktur ini menjadikan proses implementasi menjadi jauh dari efektif.

Di Indonesia sering terjadi inefektivitas implementasi kebijakan karena kurangnya koordinasi dan kerjasama diantara lembagalembaga negara dan pemerintah. Struktur birokrasi adalah kesesuaian karakteristik dan kesesuaian norma-norma dalam badan-badan eksekutif yang mempunyai hubungan baik potensial maupun nyata dengan apa yang mereka miliki dalam menjalankan kebijakan, serta kesesuaian pola-pola hubungan yang terjadi berulang-ulang dalam badan-badan eksekutif yang mempunyai hubungan baik potensial maupun nyata. Pada pembahasan mengenai hasil dalam faktor struktur birokrasi yang terdapat pada implementasi kebijakan pendataan penduduk non permanen di Kabupaten Bangka, peneliti akan menjabarnya dalam dua indikator yang terdapat pada struktur birokrasi, pembahasan terkait faktor struktur birokrasi adalah sebagai berikut:

Dari hasil penelitian dapat diketahui bahwa dalam pelaksanaan kebijakan pendataan penduduk non permanen di Kabupaten Bangka telah diatur prosedur-prosedur dasar pelaksanaan, prosedurprosedur dasar kerja atau standar operating prosedur (SOP) sangat dibutuhkan dalam pelaksanaan suatu kebijakan. Prosedur-prosedur dasar kerja adalah prosedur-prosedur atau standar yang dijadikan acuan dalam pelaksanaan suatu kebijakan, dengan adanya prosedur-prosedur dasar kerja maka implementasi kebijakan dapat sesuai dengan rencana yang telah ditetapkan sebelumnya. Hal ini sesuai dengan yang dikemukan oleh Edward III dalam Winarno (2012:207) yang mengatakan bahwa dengan menggunakan SOP para pelaksana dapat memanfaatkan waktu yang tersedia dan menyeragamkan tindakan-tindakan dari pejabat di dalam organisasi.

Secara garis besar, harapan yang diinginkan adalah terwujudnya tertib administrasi kependudukan bagi penduduk non permanen khususnya penduduk pendatang di Kabupaten Bangka. Berdasarkan pemaparan informan, hal ini dapat dilakukan dengan menggunakan prosedur 
operasi standar yang berupa teknis pelaksanaan kebijakan sudah begitu paham dan mengerti standar operasional prosedur (SOP). Maka dapat disimpulkan bahwa SOP dalam pelaksanaan kebijakan pendataan penduduk non permanen ini sudah cukup baik dilihat dari aspek SOP, yang dimana dengan sudah lengkapnya SOP tentang pelaksanaan kebijakan pendataan penduduk non permanen berdasarkan Peraturan Menteri Dalam Negeri Nomor 14 Tahun 2015 maka diharapkan kebijakan dapat menjadi konsisten.

Syarat dan Tata Cara Pendataan Penduduk Non Permanen

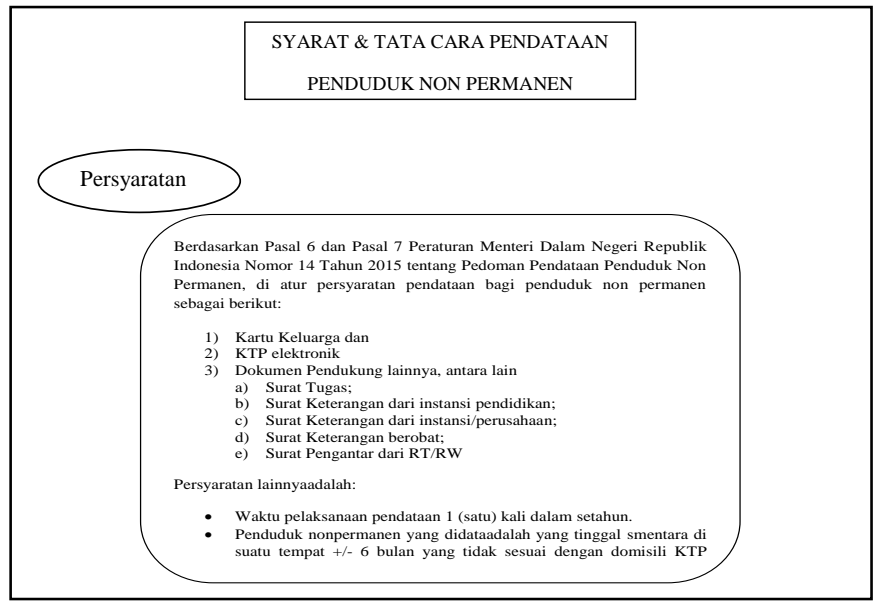

Sumber : Dinas Kependudukan dan Pencatatan Sipil Kabupaten Bangka

Pada gambar diatas merupakan syarat dan tata cara dalam pelaksanaan pendataan penduduk nonpermanen. Bisa dilihat ada beberapa syarat yang harus dipenuhi seperti kelengkap surat-menyurat misalnya kartu keluarga, KTP-el, serta dokumen pendukung lainnya.

\section{Tahapan atau Prosedur Pendataan Penduduk Nonpermanen}

PELAKSANAAN

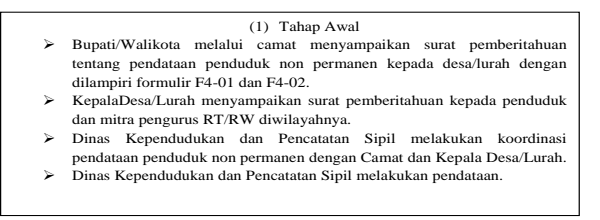

(2) Tahap Pendataan

Petugas/aparatur pendataan di tingkat Desa melalui RT/RW, melakukan pencatatan penduduk non permanen menggunakan Formulir F4-01
(Pendataan penduduk non permanen) dan F4-02 (Formulir data anggota
Sumber : Dinas Kependudukan dan Pencatatan Sipil Kabupaten Bangka

Pada gambar diatas merupakan tahapan prosedur pendataan penduduk non permanen, pelaksanaannya ada tahap awal dan tahap pendataan. Tahap awal dimulai dari Bupati/Walikota melalui Camat untuk menyampaikan surat pemberitahuan pendataan penduduk nonpermanen kepada Kepala Desa/Lurah dilampiri formulir F4-01 dan F4-02. Kemudian Kepala Desa/Lurah menyampaikan surat pemberitahuan kepada penduduk dan mitra pengurus yaitu RT/RW di wilayah setempat. Dinas Kependudukan dan Pencatatan Sipil melakukan koordinasi pendataan penduduk non permanen dengan Camat dan Kepala Desa/Lurah. Setelah itu, Dinas Kependudukan dan Pencatatan Sipil melakukan pendataan.

Struktur birokrasi memiliki pengaruh yang signifikan terhadap implementasi kebijakan. Aspek struktur birokrasi ini melingkupi dua hal yaitu mekanisme dan struktur birokrasi itu sendiri. Aspek pertama adalah mekanisme, dalam implementasi kebijakan biasanya sudah dibuat Standart Operational Procedure (SOP). SOP menjadi pedoman bagi setiap implementator dalam bertindak agar dalam pelaksanaan kebijakan tidak melenceng dari tujuan dan sasaran kebijakan. Aspek kedua adalah struktur birokrasi, struktur birokrasi yang terlalu panjang dan terfragmentasi akan cenderung melemahkan pengawasan dan menyebabkan prosedur birokrasi yang rumit dan kompleks yang selanjutnya akan menyebabkan aktivitas organisasi menjadi tidak fleksibel.

Dari hasil penelitian dapat diketahui bahwa dalam pelaksanaan kebijakan pendataan penduduk non permanen di Kabupaten Bangka telah diatur prosedur-prosedur dasar pelaksanaan, prosedurprosedur dasar kerja atau standar operating prosedur (SOP) sangat dibutuhkan dalam pelaksanaan suatu kebijakan. Prosedur-prosedur dasar kerja adalah prosedur-prosedur atau standar yang dijadikan acuan dalam pelaksanaan suatu kebijakan, dengan adanya prosedur-prosedur dasar kerja maka 
implementasi kebijakan dapat sesuai dengan rencana yang telah ditetapkan sebelumnya.

Berdasarkan hasil wawancara dengan berbagai narasumber dan observasi dilapangan beserta data-data yang peneliti temukan, pada indikator struktur birokrasi yang merupakan faktorfaktor implementasi kebijakan pendataan penduduk nonpermanen di Kabupaten Bangka dapat disimpulkan bahwa SOP yang telah dimuat dalam Peraturan Menteri Dalam Negeri Nomor 14 Tahun 2015 belum dilaksanakan dengan maksimal karena yang peneliti temukan hasil dari rekapitulasi data penduduk nonpermanen di kelurahan tidak dikirimkan ke Dinas Kependudukan dan Pencatatan Sipil melainkan hanya diarsipkan di kelurahan. Maka dapat dilihat bahwa aparatur pelaksana belum cukup memahami akan standar operating prosedur (SOP) yang sudah ada

\section{Kesimpulan}

Berdasarkan hasil penelitian dan pembahasan yang dilakukan peneliti, maka dapat dibuat kesimpulan sebagai berikut :

Implementasi kebijakan pendataan penduduk nonpermanen di Kabupaten penduduk non permanen di Kabupaten Bangka Bangka yang dilihat dari beberapa dimensi yang dikemukakan oleh Charles O. Jones dalam Joko Widodo (2007:89) yang mencakup dimensi organisasi, interprestasi dan aplikasi, hasilnya cukup baik. Hasil ini bisa dilihat secara keseluruhan, yang pertama pada dimensi organisasi sumber daya manusia untuk kompetensi dalam melaksanakan kebijakan dari pemberian wewenang dan tanggungjawab sudah cukup baik dilihat dari kegiatan pendataan penduduk nonpermanen yang sampai saat ini sudah terlaksanakan tetapi belum berjalan secara optimal. Yang kedua pada dimensi interpretasi, peneliti menemukan bahwa pemahaman dari para pelaksana kebijakan pendataan penduduk nonpermanen di Kabupaten Bangka sudah cukup baik dalam memahami akan tujuan dan sasaran kebijakan. Untuk dimensi yang terakhir yaitu aplikasi, pada dimensi aplikasi ini dapat disimpulkan bahwa dalam pelaksanannya aparatur pelaksana sudah berpedoman pada peraturan yang ada.
Faktor-faktor yang mempengaruhi implementasi kebijakan pendataan penduduk nonpermanen di Kabupaten Bangka, dilihat dari teori yang peneliti gunakan yaitu teori yang dikemukakan oleh Edward III dalam Riant Nugroho (2017:744) diantaranya, komunikasi, sumber daya, disposisi dan struktur birokrasi dapat disimpukan hasilnya belum baik. Hal ini bisa dilihat dari indikator yang pertama yaitu komunikasi, masih kurangnya komunikasi yang diberikan oleh aparatur pelaksana dari tingkat atas ke tingkat bawah maupun dari tingkat bawah kepada masyarakat yang mayoritas masyarakat belum mengetahui akan adanya kebijakan pendataan penduduk nonpermanen. Indikator yang kedua yaitu sumber daya, kekurangan sumber daya manusia menjadi kendala dalam upaya implementor menyampaikan keluaran kebijakan kepada kelompok sasaran. Indikator yang ketiga yakni disposisi, komitmen aparatur pelaksana dalam implementasi kebijakan pendataan penduduk non permanen di Kabupaten Bangka dapat dikatakan cukup baik. Untuk indikator yang ke empat yaitu struktur birokrasi, dimana aparatur pelaksana belum cukup memahami akanstandar operating procedure (SOP) yang sudah.

\section{Daftar Pustaka}

Djamal, M. 2015. Paradigma Penelitian Kualitatif. Yogyakarta: Mitra Pustaka

Nugroho D, Riant, Public Policy: Teori KebijakanAnalisis Kebijakan Proses Kebijakan, Perumusan, Implementasi, Evaluasi, Revisi, Risk Manajement dalam Kebijakan Publik, Kebijakan sebagai The Fith Estate, Metode Kebijakan, PT. Elex Media Komputindo, Jakarta, 2008

Nugroho D, Riant, Public Policy: Dinamika Kebijakan Publik, Analisis Kebijakan Publik, Manajemen Politik Kebijakan Publik, Etika Kebijakan Publik, Kimia Kebijakan Publik Edisi 6, PT. Elex Media Komputindo, Jakarta, 2017.

Soehartono, Irawan, Metode Penelitian Sosial, PT. Remaja Rosdakarya, Bandung, 2002.

Simanjuntak, P.N.H, Hukum Perdata Indonesia, Prenada Media, Jakarta, 2014.

Sugiyono, Metode Penelitian Kualitatif dan Kuantitatif, Penerbit Alfabeta, Bandung, 2007. 
Soepomo, R, Hukum Pidana, Sinar Grafika, Jakarta, 2007.

Widodo, Joko, Analisis Kebijakan Publik: Konsep dan Aplikasi Analisis Proses Kebijakan Publik, Bayu Media Publishing, Malang, 2007.

Winarno, Budi, Teori dan Proses Kebijakan Publik, Media Pressindo, Yogyakarta, 2005.

Winarno, Budi, Kebijakan Publik: Teori dan Proses

Edisi Revisi, Media Pressindo, Yogyakarta, 2007. 